Jap. J. Limnol. 44, 2, 123-131, 1983.

\title{
Evaluation of Extraction Techniques for the Determination of Heavy Metals in River Sediments
}

\author{
Norito Watanabe, Yutaka Yasuda, Kunio Kato, Tetsuo \\ Nakamura, Kohei Shimokawa and Youki Ose
}

\begin{abstract}
In order to distinguish whether heavy metal contents originate from a rock matrix or pollution, six different extraction techniques for copper, lead and cadmium were studied in Nagara River sediments in Gifu Prefecture, Japan. The extraction agents were hydrochloric-nitric acid mixture $(1+1)$, $3 \mathrm{~N}$ hydrochloric acid solution, $0.5 \mathrm{~N}$ hydrochloric acid solution, $6 \mathrm{M}$ formic acid solution, $1 \mathrm{~N}$ hydroxylamine hydrochloride plus $25 \%$ acetic acid solution and $0.05 \mathrm{~N}$ ethylenediaminetetraacetic acid solution.

The comparison of the six extraction techniques was conducted on the basis of the heavy metal contents originating from pollution, which was estimated by subtracting background values from total contents. For copper, $3 \mathrm{~N}$ hydrochloric acid is preferable, but in sediments with poor ignition loss, $0.5 \mathrm{~N}$ hydrochloric acid and $6 \mathrm{M}$ formic acid are recommended. $1 \mathrm{~N}$ hydroxylamine hydrochloride plus $25 \%$ acetic acid is suitable for lead and cadmium.
\end{abstract}

\section{Introduction}

Various extraction methods have been applied for the determination of heavy metals in aquatic sediments. In Japan, a sediment analytical method involving hydrochloric-nitric extraction is commonly employed for the evaluation of environmental pollution by heavy metals (WATER QUALITY Bureau, Environmental Agency of Japan, 1975). Extraction with such a strong mineral acid assures highly effective extraction of heavy metals and is advantageous for the simultaneous determination of a large number of metals. On the other hand, a rock mineral can be partially attacked (AGEMIAN et al., 1976), so it is difficult to evaluate strictly the degree of pollution by heavy metal only with the results obtained by the above method.

Some selective extraction methods using hydrochloric acid, ethylenediaminetetraacetic acid and hydroxylamine hydrochloride plus acetic acid were proposed by RAY et al. (1957), GoldBerg et al. (1958) and Chester et al. (1967), in order to investigate the partitioning of trace elements in marine sediments. These methods were applied for difterent environmental samples, e. g., river sediments (TADA et al., 1976 a, b; Agemian et al., 1976; TADA et al., 1979; LUONA et al., 1981), lake sediments (OTsuKa, 1981), marine sediments (CHESTER et al., 1967; ITo et al., 1975, 1976; KiTANO et al., 1980 a, b) and soils (MAYNARD et al., 1973; BRADSHAw et al., 1974). Their heavy metal content and existing forms were also discussed. However, little effort has been made to ascertain the availability of extraction methods to distinguish between heavy metal contents originating from rock matrix and those from pollution (TADA et al., 1976; AgEmian et al., 1976). The aim of this work is mainly to demonstrate the effectiveness of different extraction methods by applying them to copper, lead and cadmium in river sediments.

\section{Experimental}

\section{2-1. Sample collection and treatment}

Figure 1 shows the river sediment sampling locations. One sediment sample was collected from each station in the Nagara River (Gifu Prefecture) in June 1981, and six samples were taken at St. 8. Sediment 


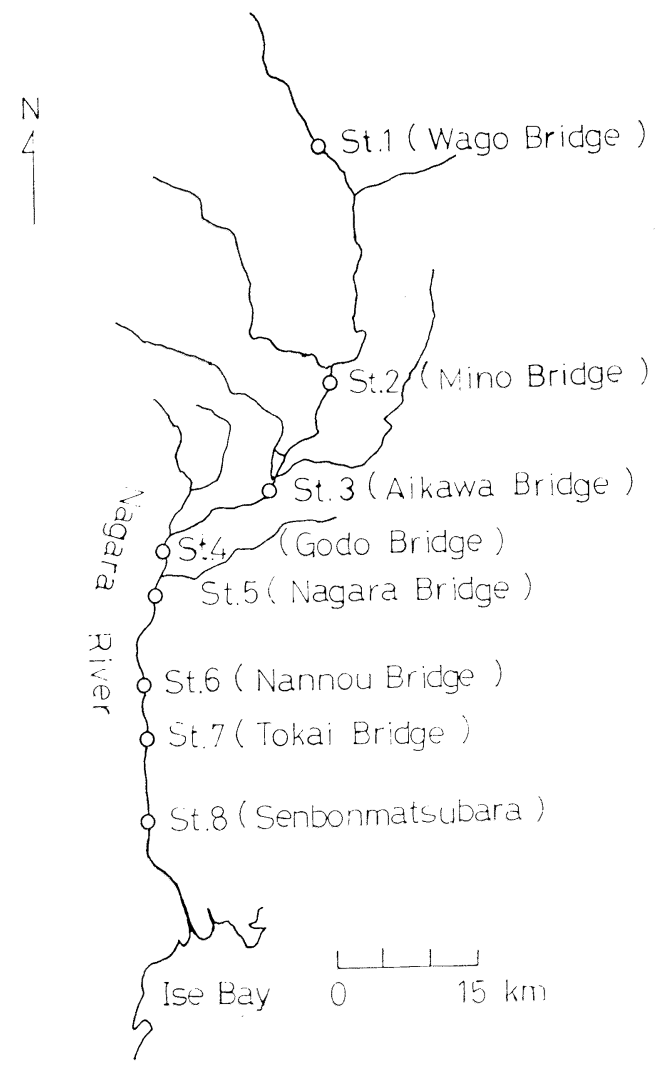

Fig. 1. Location of sampling stations of the river sediments in the Nagara River.

samples were scooped from approximately $10 \mathrm{~cm}$ depth with a stainless-steel trowel and transported to the laboratory, where they were sieved to less than $2 \mathrm{~mm}$ and centrifuged at $3,000 \mathrm{rpm}$ for $20 \mathrm{~min}$.

\section{2-2. Heavy metal extraction systems}

Hydrochloric-nitric acid mixture $(1+1)$ extraction (method A); $5 \mathrm{~g}$ of sediment was leached with $20 \mathrm{ml}$ of boiling hydrochloric-nitric acid mixture $(1+1)$ for $2 \mathrm{hrs}$ (Water Quality Bureau, Environmental Agency of Japan, 1975).

$3 \mathrm{~N}$ hydrochloric acid extraction (method B); $10 \mathrm{~g}$ of sediment was leached with 30 $\mathrm{m} l$ of $3 \mathrm{~N}$ hydrochloric acid in a water bath for $3 \mathrm{hrs}$ (RAY et al., 1957).

$0.5 \mathrm{~N}$ hydrochloric acid extraction (method C); $10 \mathrm{~g}$ of sediment was leached with $100 \mathrm{ml}$ of $0.5 \mathrm{~N}$ hydrochloric acid and shaken for $8 \mathrm{hrs}$ at room temperature (MAYNARD et al., 1973).
$6 \mathrm{M}$ formic acid extraction (method $\mathrm{D}$ ); $10 \mathrm{~g}$ of sediment was heated with $50 \mathrm{~m} l$ of $6 \mathrm{M}$ formic acid in a water bath for 1 hr (RAy et al., 1957).

$1 \mathrm{~N}$ hydroxylamine hydrochloride plus $25 \%$ acetic acid extraction (method $\mathrm{E}$ ); $5 \mathrm{~g}$ of sediment was leached with $60 \mathrm{~m} l$ of hydroxylamine hydrochloride and $140 \mathrm{~m} l$ of $35 \%$ acetic acid and shaken for $4 \mathrm{hrs}$ at room temperature (CHESTER et al., 1967).

$0.05 \mathrm{~N}$ ethylenediaminetetraacetic acid extraction (method $\mathrm{F}$ ); $5 \mathrm{~g}$ of sediment was leached with $100 \mathrm{~m} l$ of $0.05 \mathrm{~N}$ ethylenediaminetetraacetic acid and shaken for $8 \mathrm{hrs}$ at room temperature (MAYNARD et al., 1973).

\section{2-3. Apparatus}

Measurements of copper, lead and cadmium were made with a Hitachi, Model 308, atomic absorption spectrophotometer equipped with a triple-slot air-acetylene burner. Air and acetylene pressure were 1.8 and $0.5 \mathrm{~kg} \cdot \mathrm{cm}^{-2}$, respectively. PerkinElmer Intensitron lamps were used for the determination.

\section{2-4. Extraction procedure of heavy metals}

For determining heavy metals, the DDTC-MIBK extraction method was used (Water Quality Bureau, Environmental Agency of Japan, 1975).

\section{2-5. Ignition loss}

Ignition loss data were obtained from weight loss by ignition to $550^{\circ} \mathrm{C}$ for $2 \mathrm{hrs}$ (Water Quality Bureau, Environmental Agency of Japan, 1975).

\section{Results and Discussion}

3-1. Comparison of extractabilities of heavy metals in sediments by different extraction systems

Applying six extraction methods described in 2-2. for the samples collected from St. 8, copper, lead and cadmium were analyzed and analytical results of these metals were given in Table 1 . The metal contents determined by the method $\mathrm{A}$ were the highest in every sediment sample. The extractabilities of each metal calculated from the basis of the results with method A were summarized in Table 2 . 
Table 1. Analytical results of heavy metals in the river sediments of the Nagara River (St. 8) using different extraction system.

\begin{tabular}{lccccccc}
\hline Metal & $\begin{array}{l}\text { Ignition } \\
\text { loss }(\%)\end{array}$ & A & B & C & D & E & F \\
& 1.0 & 7.71 & 5.39 & 3.17 & 4.06 & 3.19 & 3.28 \\
& 1.0 & 7.07 & 4.65 & 3.89 & 3.11 & 3.28 & 2.81 \\
Copper & 1.3 & 11.2 & 7.69 & 5.57 & 6.07 & 5.13 & 7.80 \\
$\left(\mu \mathrm{g} \cdot \mathrm{g}^{-1}\right)$ & 1.7 & 11.9 & 7.87 & 7.40 & 6.58 & 4.25 & 4.36 \\
& 2.3 & 15.5 & 13.8 & 9.39 & 10.8 & 8.40 & 7.10 \\
& 4.5 & 33.2 & 30.4 & 24.6 & 24.0 & 15.6 & 18.5 \\
& $(1.7)$ & $(12.4)$ & $(9.27)$ & $(6.99)$ & $(7.12)$ & $(5.57)$ & $(5.87)$ \\
\hline & 1.0 & 8.88 & 6.15 & 3.69 & 3.81 & 0.90 & 2.30 \\
& 1.0 & 8.91 & 6.81 & 3.94 & 3.07 & 2.30 & 2.04 \\
Lead & 1.3 & 9.23 & 8.47 & 6.12 & 5.75 & 4.89 & 4.02 \\
$\left(\mu \mathrm{g} \cdot \mathrm{g}^{-1}\right)$ & 1.7 & 11.2 & 10.1 & 7.27 & 5.19 & 6.31 & 4.48 \\
& 2.3 & 13.3 & 10.3 & 8.69 & 5.79 & 7.74 & 5.75 \\
& 4.5 & 20.6 & 17.3 & 16.0 & 14.6 & 12.7 & 10.9 \\
& $(1.7)$ & $(11.4)$ & $(9.28)$ & $(6.69)$ & $(5.56)$ & $(4.30)$ & $(4.18)$ \\
\hline & 1.0 & 0.26 & 0.20 & 0.11 & 0.09 & 0.06 & 0.07 \\
& 1.0 & 0.25 & 0.16 & 0.07 & 0.10 & 0.03 & 0.04 \\
& 1.3 & 0.37 & 0.18 & 0.13 & 0.12 & 0.01 & 0.08 \\
Cadmium & 1.7 & 0.32 & 0.20 & 0.12 & 0.13 & 0.10 & 0.09 \\
$\left(\mu \mathrm{g} \cdot \mathrm{g}^{-1}\right)$ & 2.3 & 0.39 & 0.22 & 0.21 & 0.17 & 0.19 & 0.10 \\
& 4.5 & 0.55 & 0.36 & 0.30 & 0.35 & 0.07 & 0.28 \\
& $(1.7)$ & $(0.34)$ & $(0.21)$ & $(0.14)$ & $(0.14)$ & $(0.05)$ & $(0.09)$ \\
\hline
\end{tabular}

Values in parentheses denote geometric mean.

A, nitric-hydrochloric acid $(1+1) ; \mathrm{B}, 3 \mathrm{~N}$ hydrochloric acid; C, $0.5 \mathrm{~N}$ hydrochloric acid; D, $6 \mathrm{M}$ formic acid; E, $1 \mathrm{~N}$ hydroxylamine hydrochloride $+25 \%$ acetic acid; F, $0.05 \mathrm{~N}$ ethylenediaminetetraacetic acid.

Table 2. Percentage of extraction of heavy metals by six extraction methods.

\begin{tabular}{lcccccc}
\hline Metal & \multicolumn{5}{c}{ Metal, $\mu g \cdot g^{-1}$} & by method A, B, C, D, E or F \\
\cline { 2 - 5 } & Metal, & $\mu \mathrm{g} \cdot \mathrm{g}^{-1}$ & by & method A & & \\
& A & B & C & D & E & F \\
Copper & 100 & $75 \pm 11$ & $57 \pm 10$ & $58 \pm 10$ & $45 \pm 6$ & $48 \pm 11$ \\
Lead & 100 & $82 \pm 8$ & $60 \pm 13$ & $50 \pm 13$ & $44 \pm 19$ & $38 \pm 11$ \\
Cadmium & 100 & $64 \pm 7$ & $43 \pm 9$ & $44 \pm 9$ & $22 \pm 15$ & $29 \pm 11$ \\
\hline
\end{tabular}

Data for copper, lead and cadmium from Table 1 referred to the results with hydrochloric-nitric acid method.

A, hydrochloric-nitric acid; B, 3N hydrochloric acid; C, $0.5 \mathrm{~N}$ hydrochloric acid; $\mathrm{D}, 6 \mathrm{M}$ formic acid; $\mathrm{E}, 1 \mathrm{~N}$ hydroxylamine hydrochloride $+25 \%$ acetic acid; F, 0.05N ethylenediaminetetraacetic acid.

The percentage of extraction in these methods were in the order $\mathrm{A}>\mathrm{B}>\mathrm{D} \geqq \mathrm{C}>$ $\mathrm{F}>\mathrm{E}$ for copper, $\mathrm{A}>\mathrm{B}>\mathrm{C}>\mathrm{D}>\mathrm{E}>\mathrm{F}$ for lead, and $A>B>D \geqq C>F>E$ for cadmium. Among the method $\mathrm{C}, \mathrm{E}$ and $\mathrm{F}$, which are well used as the selective extraction methods, the method $\mathrm{C}$ showed higher values than other methods, but there was no noticeable difference between the methods $E$ and $F$.

3-2. Availability of extraction methods for heavy metals in sediments originating from pollution

Heavy metal contents originating from 
pollution in river sediments may be estimated by subtracting background values from total contents. In general, background values of heavy metals in river sediments have been analogized by heavy metal contents in sediments from non-polluted areas of the same watershed under the hypothesis that the geology of the survey area is similar to that of the non-polluted area (OKADA et al., 1977; KUBo et al., 1977).

In the previous study, the present authors investigated the background values of heavy metals in Nagara River sediments using the hydrochloric-nitric acid extraction method, and revealed that the background values of copper, lead and cadmium were $3.5 \mu \mathrm{g} \cdot \mathrm{g}^{-1}, \quad 6.4 \mu \mathrm{g} \cdot \mathrm{g}^{-1}$ and $0.24 \mu \mathrm{g} \cdot \mathrm{g}^{-1}$, respectively (SHImoKawa et al., $1980 \mathrm{a}$ ).
These data could not be strictly regarded as background values because hydrochloricnitric acid does not liberate all of the metals from the silicate matrix. However, they are sufficient to estimate the heavy metal contents originating from pollution when total contents are obtained by the same technique. Thus, the method's lack of extractability can be deleted in the calculating process.

Hence, the copper, lead and cadmium contents in sediments originating from pollution were estimated from the data shown in Table 1 , column 2 and the background values described above; then the heavy metal contents obtained by different extraction methods were compared to the estimated values. It is apparent

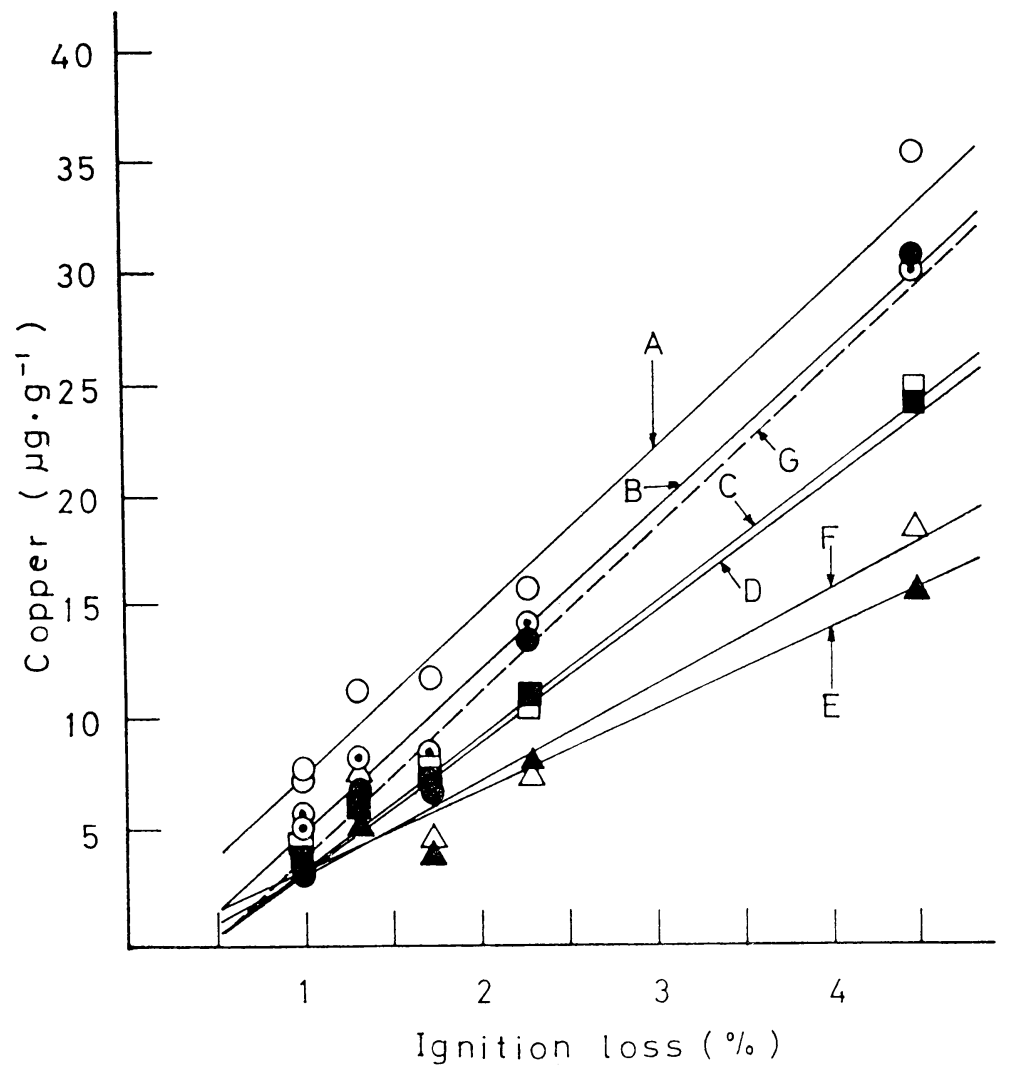

Fig. 2. Relations of copper by different extraction methods and ignition loss in sediments.

A, hydrochloric-nitric acid; $\mathrm{B}, 3 \mathrm{~N}$ hydrochloric acid; C, $0.5 \mathrm{~N}$ hydrochloric acid; $\mathrm{D}, 6 \mathrm{M}$ formic acid; E, $1 \mathrm{~N}$ hydroxylamine hydrochloride $+25 \%$ acetic acid; F, $0.05 \mathrm{~N}$ ethylenediaminetetraacetic acid; G, A-background value (estimated from the analytical data of sediments in the upper reach of the Nagara River) 
from Table 1 that heavy metal contents generally increase with increasing ignition loss. The measured and estimated pollutant values ( $Y$ ) were found to be related to ignition loss $(\mathrm{X})$ in the following form at $1 \%$ significance $\mathrm{Y}=\mathrm{AX}+\mathrm{B}$ empirically. Then, a comparison of the six extraction methods was made on the basis of the above relationship.

Figure 2 shows the relationship of copper contents and ignition loss in sediments. Analytical results by the method B were in good agreement with the estimated values over the whole range of ignition loss. With methods $\mathrm{C}$ and $\mathrm{D}$, a fair agreement was recognized in the range of lower ignition loss (less than $2 \%$ ), but in the range of higher ignition loss the measured values were somewhat lower than the estimated ones. The method A gave higher values, whereas methods $\mathrm{E}$ and $\mathrm{F}$ gave lower values, than the estimated values.

Figure 3 shows the relationship of lead contents and ignition loss in sediments. Methods $\mathrm{D}$ and $\mathrm{E}$ were preferable in the overall range of ignition loss. Methods A, $\mathrm{B}$ and $\mathrm{C}$ gave higher than the estimated values in the whole range of ignition loss, but the method $\mathrm{F}$ generally gave lower values in the higher range of ignition loss.

Figure 4 shows the relationship of cadmium contents and ignition loss in sediments. Results of the method $\mathrm{E}$ were approximately in accord with the estimated values. All but the method $F$ extraction method gave higher than the estimated

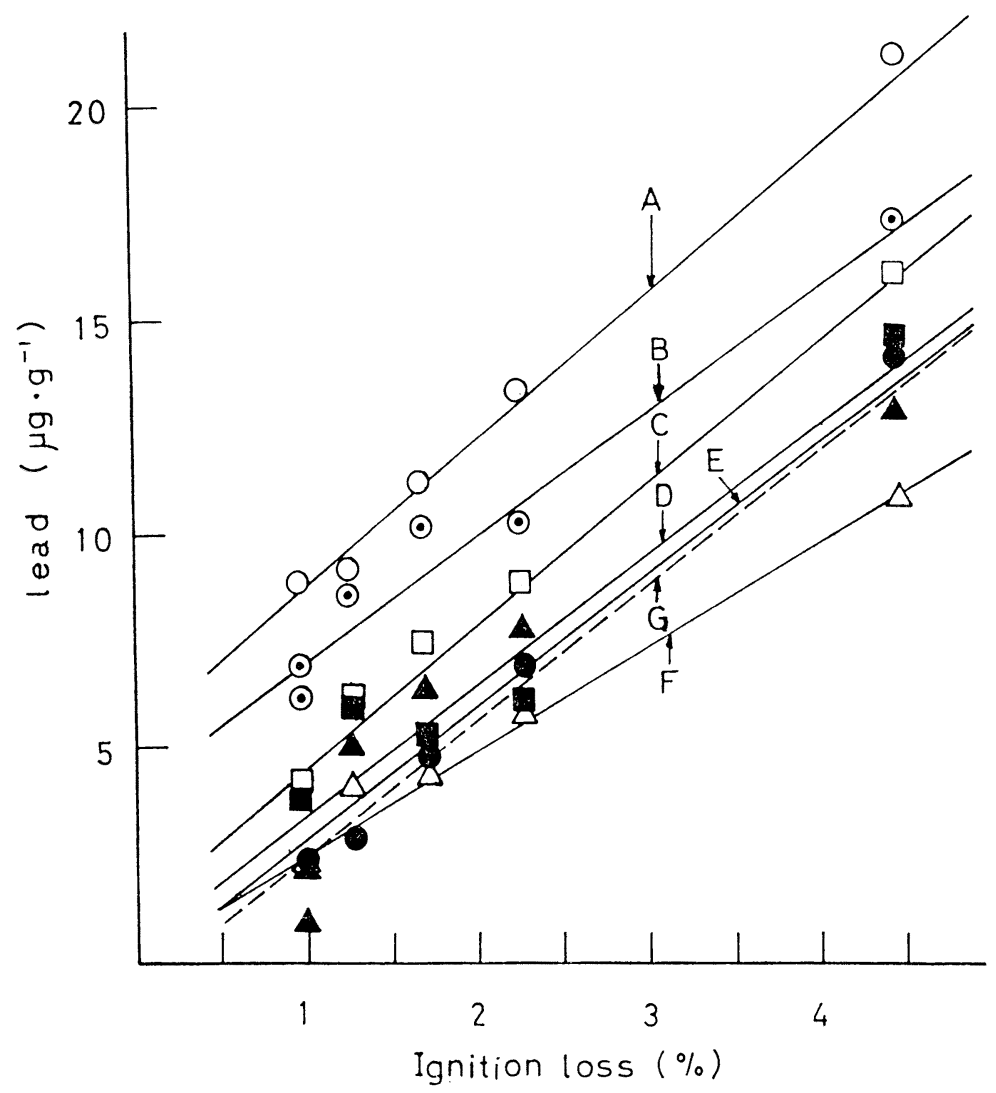

Fig. 3. Relations of lead by different extraction methods and ignition loss in sediments.

A, hydrochloric-nitric acid; $\mathrm{B}, 3 \mathrm{~N}$ hydrochloric acid; $\mathrm{C}, 0.5 \mathrm{~N}$ hydrochloric acid; D, $6 \mathrm{M}$ formic acid; E, $1 \mathrm{~N}$ hydroxylamine hydrochloride $+25 \%$ acetic acid; $\mathrm{F}, 0.05 \mathrm{~N}$ ethylenediaminetetraacetic acid; G, A-background value (estimated from the analytical data of sediments in the upper reach of the Nagara River) 


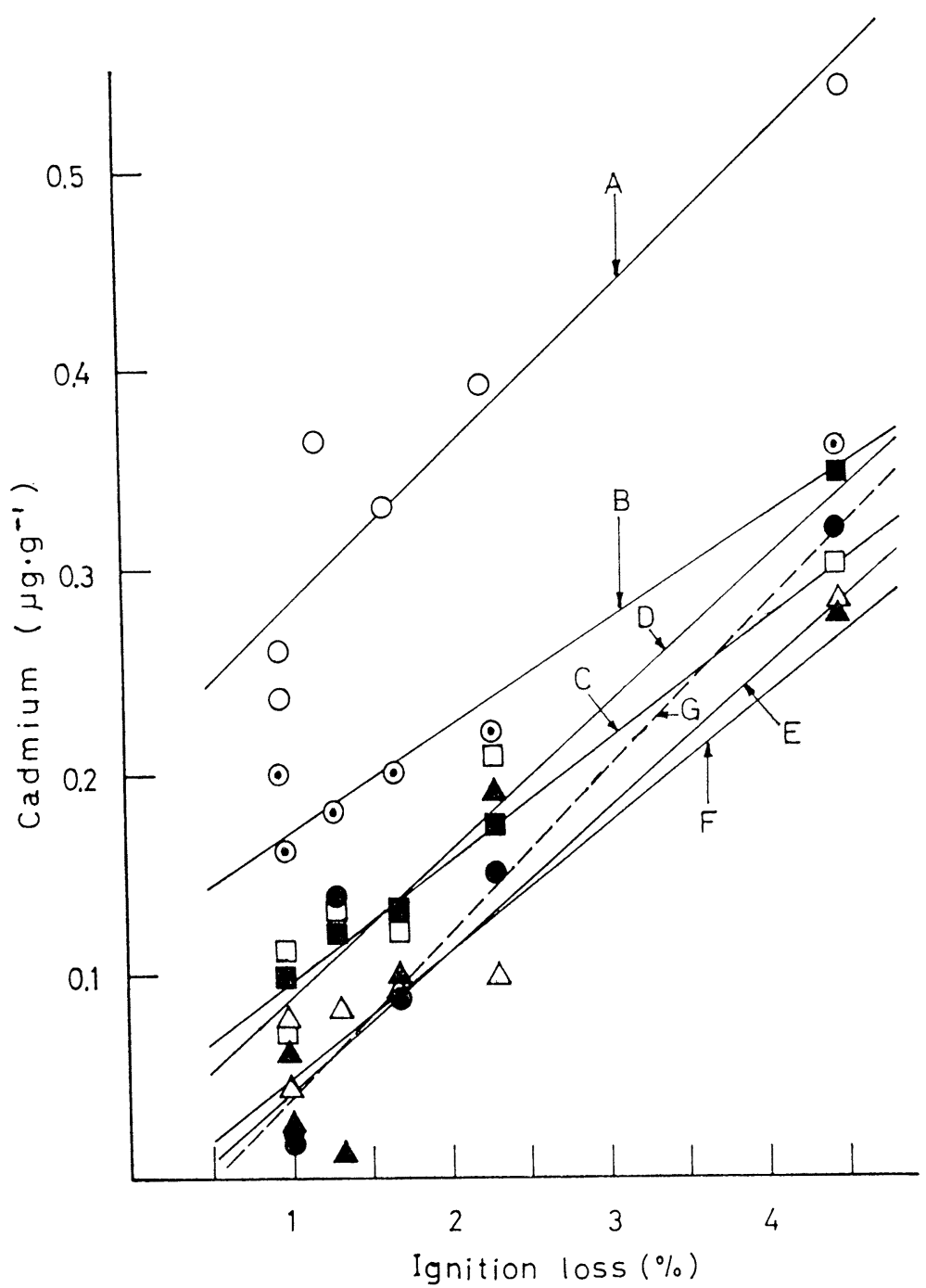

Fig. 4. Relations of cadmium by different extraction methods and ignition loss in sediments.

A, hydrochloric-nitric acid; $\mathrm{B}, 3 \mathrm{~N}$ hydrochloric acid; $\mathrm{C}, 0.5 \mathrm{~N}$ hydrochloric acid; D, $6 \mathrm{M}$ formic acid; E, $1 \mathrm{~N}$ hydroxylamine hydrochloride+ $25 \%$ acetic acid; F, $0.05 \mathrm{~N}$ ethylenediaminetetraacetic acid; G, A-background value (estimated from the analytical data of sediments in the upper reach of the Nagara River)

values. In fact, method $\mathrm{F}$ gave appreciably lower values in the range of higher ignition loss.

3-3. Application of some extraction methods to the sediments from several stations in the Nagara River

Table 3 gives a description of sediment samples collected from 7 stations in the
Nagara River. The linear relationships between the estimated pollutant value (Y) and the ignition loss (X) obtained from the data for St. 8 were as follows; $Y=7.21 \mathrm{X}$ -3.26 for copper, $\mathrm{Y}=3.08 \mathrm{X}-0.63$ for lead, $\mathrm{Y}=0.080 \mathrm{X}-0.039$ for cadmium. The estimated pollutant values in the sediments from the sampling stations except St. 8 
Table 3. Description of sediment samples.

\begin{tabular}{clrll}
\hline Station & $\begin{array}{c}\text { Sample } \\
\text { location }\end{array}$ & $\begin{array}{c}\text { Distance from } \\
\text { coastline }\end{array}$ & $\begin{array}{l}\text { Sediment } \\
\text { type }\end{array}$ & $\begin{array}{l}\text { Ignition } \\
\text { loss }(\%)\end{array}$ \\
\hline 1 & Wago Bridge & 112 & Sand & 1.6 \\
2 & Mino Bridge & 75 & Silty sand & 1.6 \\
3 & Aikawa Bridge & 59 & Fine sand & 1.0 \\
4 & Goudo Bridge & 45 & Silty sand & 2.9 \\
5 & Nagara Bridge & 39 & Fine sand & 1.4 \\
6 & Nannou Bridge & 28 & Silty sand & 3.0 \\
7 & Tokai Bridge & 22 & Anaerobic mud & 3.1 \\
\hline
\end{tabular}

could be calculated by substituting the ignition loss values listed in Table 3 in the above equations. Then, on the basis of these estimated pollutant values, the effectiveness of methods $\mathrm{C}$ and $\mathrm{E}$ was studied, because they were commonly used for the determination of metals originating from polluted water. The copper, lead and cadmium results were illustrated in Figs. 5, 6 and 7 , respectively.

In Fig. 5, the measured values by the method $C$ were in good agreement with estimated values. The results do not conflict

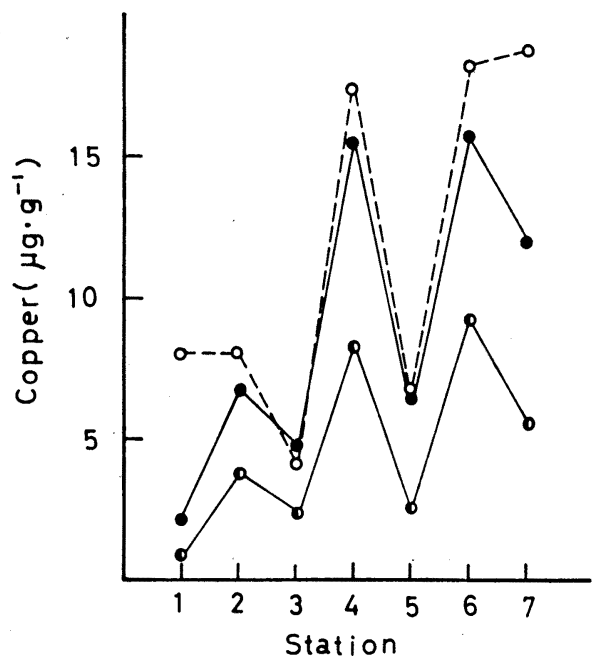

Fig. 5. Distribution of copper in sediments of the Nagara River with two extraction methods.

, copper contents with $0.5 \mathrm{~N}$ hydrochloric acid; $O$, copper contents with 1N hydroxylamine hydrochloride $+25 \%$ acetic acid; $\bigcirc$, estimated copper contents originating from pollution. with the information obtained in 3-2. because the ignition loss of sediment samples was relatively low (less than $3 \%$ ). Method E showed lower than the estimated values for all sediment samples.

In Fig. 6, the estimated values were

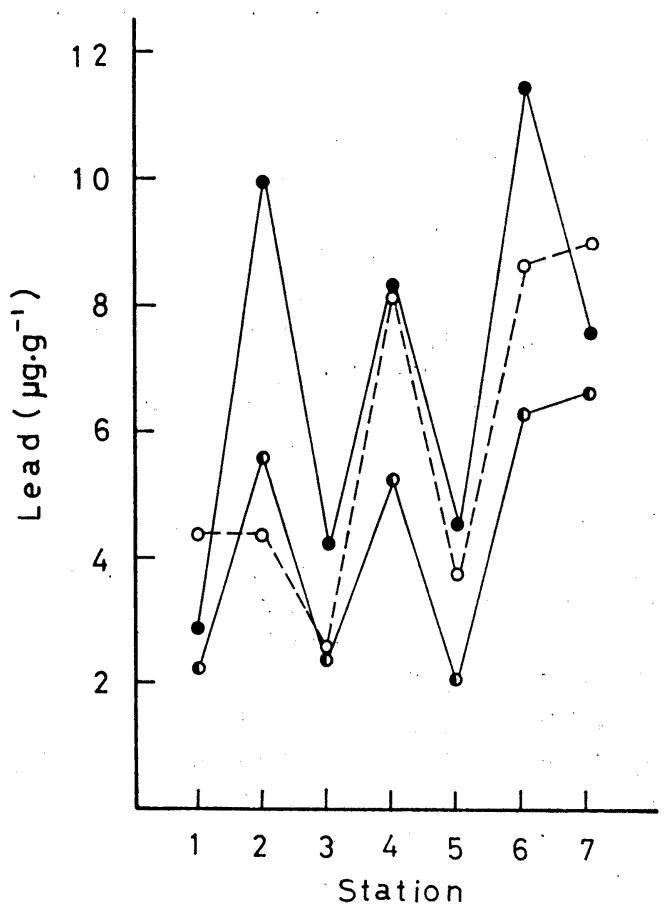

Fig. 6. Distribution of lead in sediments of the Nagara River with two extraction method.

, lead contents with $0.5 \mathrm{~N}$ hydrochloric acid; 1 , lead contents with $1 \mathrm{~N}$ hydroxylamine hydrochloride $+25 \%$ acetic acid; $\bigcirc$, estimated lead contents originating from pollution. 


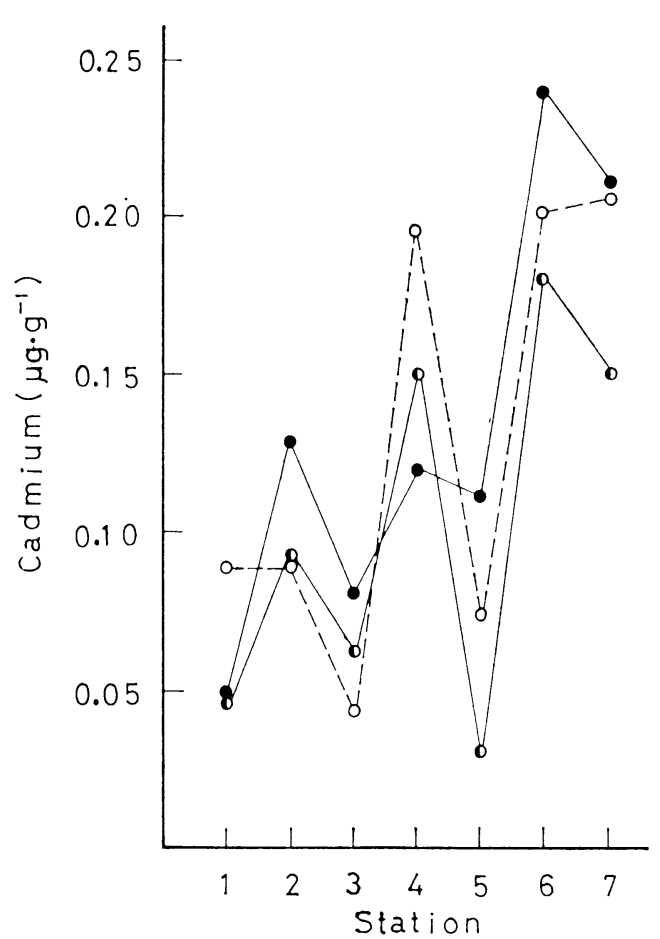

Fig. 7. Distribution of cadmium in sediments of the Nagara River with two extraction method.

, cadmium contents with $0.5 \mathrm{~N}$ hydrochloric acid; cadmium contents with $1 \mathrm{~N}$ hydroxylamine hydrochloride+ 25\% acetic acid; $\bigcirc$, estimated cadmium contents originating from pollution.

intermediate between the values measured by method $\mathrm{C}$ and those by method $\mathrm{E}$, but rather near the values by method $\mathrm{E}$. The results were almost consistent with those shown in Fig. 3.

In Fig. 7, the method $\mathrm{E}$ showed good conformity with the estimated values, but the results mostly coincide with those shown in Fig. 4.

For the selective extraction of lead and cadmium in sediments originating from pollution, methods $\mathrm{D}$ and $\mathrm{E}$ using a weak extracting agent would be preferable. For copper, methods using a stronger extracting agent (e.g., method $\mathrm{B}$ or $\mathrm{C}$ ) are required. It may be due to the fact that copper can be strongly complexed with organic compounds (SchNizer et al., 1967).

\section{Acknowledgements}

We would like to thank Mr. S. Nishiwaki, President of the Gifu Prefectural Research Institute for Environmental Pollution, for his valuable suggestions and publication permission.

\section{摘 要}

岐皁県長良川の底質中の銅, 鉊およびカドミウムに ついて, 硝酸一塩酸混液 $(1+1)$ 抽法法, $3 \mathrm{~N}$ 塩酸 溶液抽出法, $6 \mathrm{M}$ 蟻酸溶液抽出法, $1 \mathrm{~N}$ 塩酸七ド口 キシルアミン+25\%酷酸溶液抽出法および $0.05 \mathrm{M}$ EDTA“溶液抽出法を用いて，それぞれの金属元素を 定量し，污染由来推定重金属量（间河川上流部底質の 分析値をバックグラウンド值として算出）と比較し, 各抽出法の污染由来重金属抽出法としての有效性を検 討した。

銅は， $3 \mathrm{~N}$ 塩酸抽出法による測定值がもっとも污 染由来重金属量と一致した。また, 強熱減量の少ない $(1 \sim 2 \%)$ 武料については， $0.5 \mathrm{~N}$ 塩酸あるいは $6 \mathrm{M}$ 蟻酸によっても比較似良好な結果が得られた。 鉊は, $6 \mathrm{M}$ 蟻酸抽出法わよび $1 \mathrm{~N}$ 塩酸ヒドロキシル アミン $+25 \%$ 酢酸抽出法が他の抽出法に比して優れ ていた。 カドミウムは, $1 \mathrm{~N}$ 塩酸ヒドロキシルアミン +25\% 醀酸法が他の抽出法に比して優れていた。

\section{References}

Agemian, H. A. and S. Y. Chau (1976) : Evaluation of extraction techniques for the determination of metals in aquatic sediments. Analyst, 101: 761-767.

Bradshaw, P. M. D., I. Thompson, B. W. Smee and J. O. LARSon (1974): The application of different analytical extractions and soil profile sampling in exploration geochemistry. $J$. Geochem. Explor., 3: 209-225.

Chester R. and M. J. Hughes (1967) : A chemical technique for the separation of ferro-manganese minerals, carbonate minerals and adsorbed trace elements from pelagic sediments. Chem. Geol., 2: 249-262.

Goldberg, E. D. and G. O.S. Arrhenius (1958) : Chemistry of Pacific pelagic sediments. Geochim. Cosmochim. Acta., 13: 153-212.

Ito, K., S. Kojima and Y. Naruse (1975) : Heavy metals pollution of bottom muds in Nagoya Harbour. Nagoya-shi Kogai Kenkyu Shoho, 4: 45-54. (in Japanese)

Ito, K., Y. Naruse, S. Kojima and T. HaseGAwA (1976) : Behavior of heavy metals in water and bottom sediments in Nagoya Port. Nagoya-shi Kogai Kenkyu Shoho, 5: 53-57. (in Japanese) 
Kitano, Y. and R. Fujiyoshi (1980 a) : Selective chemical leaching of cadmium, copper, manganese and iron in marine sediments. Geochem. J., 14: 113-122.

Kitano, Y. and R. Fujiyoshi (1980 b) : Partitioning of cadmium, copper, manganese and iron into mineral and organic fractions in core sediments from the Osaka Bay. Geochem. J., 14: 289-301.

Kubo, K., M. Touoka, S. Nagayama and K. Miyata (1977) : Studies on heavy metals of river sediments in Kumamoto Prefecture. Kumamoto-ken Eisei Kogai Kenkyu Shoho: 45-48. (in Japanese)

Luon A, S. N. (1981) : A statistical assessment of the form of trace metals in oxidized estuarine sediments employing chemical extractants. Sci. Total Environ., 17: 165-196.

Maynard, D.E. and W.K. Fletchner (1973): Comparison of total and partial extractable copper in anomalous and background peat samples. J. Geochem. Explor., 2: 19-24.

Naruse, Y., R. Ando, F. Tsuchiyama and K. Banno (1980): Heavy metals pollution in rivers of Nagoya City. Nagoya-shi Kogai Nenkyu Shoho, 10: 27-28. (in Japanese)

Ogura, H., I. Yarita, S. Kobayashi and J. Nakajima (1979) : Mechanism of metal accumulation of sediments of Edogawa and Murata rivers. Suishitsu Odaku Kenkyu, 2: 173-180. (in Japanese)

Окаda, K., T. Yамамото, Y. Takada, K. Kusunoki, M. Miyahisa and Y. Soga (1977): Proposal and tentative plan of environmental maps. Kogai to Taisaku, 13: 12-19. (in Japanese)

Orsuka, H. (1982) : Forms of heavy metals in the settling matter from a man-made lake. Jap. J. Limnol., 43: 28-39. (in Japanese)

Ray, L., H. R. Gault and C.G. Dodd (1957) : The separation of clay minerals from carbonate rocks. Am. Mineralogist, 42: 681686.

Schnizer, M. and S.I.M. Skinner (1967): Organo-metallic interaction in soils. Soil Sci., 104: 247-252.

Shimokawa, K., H. Takada, Y. Yasuda, N. Watanabd and Y. Ose (1979a) : Particle size distribution of river sediments (I). Suishitsu Odaku Kenkyu, 2: 85-88. (in Japanese)

Shimokawa, K., H. Takada, N. Watanabe, Y. Yasuda and Y. Ose (1979 b) : Particle size distribution of river sediments (II). Suishitsu Odaku Kenkyu, 2: 152-156. (in Japanese)

Shimokawa, K., H. Takada, N. Watanabe, N. Hara, H. Mori, Y. Yasuda and Y. Ose (1980 a) : Correlation between heavy metals, ignition loss and clay in bottom sediments of the lower reach of Nagara River. Suishitsu Odaku Kenkyu, 3: 37-42. (in Japanese)

Shimokawa, K., H. Takada, N. Watanabe, H. Mori, N. Hara, Y. Yasuda and Y. Ose $(1980 \mathrm{~b})$ : Correlation between cation-exchange capacity and ignition loss, clay fraction or heavy metal content in bottom sediments from the Nagara River. Suishitsu Odaku Kenkyu, 3: 181-186. (in Japanese)

Tada, F., T. Takashima, N. Kawaguchi, $H$. Dor and S. Suzuki (1976 a) Distribution of heavy metals in bottom mud of river (V). J. Hyg. Chem., 22: 339-344. (in Japanese)

Tada, F., K. Yamazaki, T. Takashima and S. Suzuki (1976 b) : Distribution of heavy metals in bottom mud of river (IV). Jap. J. Limnol., 37: 100-107. (in Japanese)

TAdA, F. and S. Suzuki (1979) : Distribution of heavy metals in bottom mud of river (VII). Jap. J. Limnol., 40: 153-161.

Water Quality Bureau, Environmental Agency of J APAN (1975): Measuring Method for Bottom Sediments. (in Japanese)

(著者 : 渡辺憲人 - 安田裕 - 加藤邦夫 - 中村哲夫 下川洪平, 岐皋県公害研究所, 岥是市數田 8 丁目 58-2; 小瀬洋喜, 岐阜薬科大学, 岐皁市三田洞東 5-6-1; Norito Watanabe, Yutaka Yasuda, Kunio Kato, Tetsuo Nakamura, Kohei Shimokawa, Gifu Prefectural Research Institute for Environmental Pollution, 8-58, Yabuta, Gifu-shi 500; Youki Ose, Gifu College of Pharmacy, 5-6-1 Mitahorahigashi, Gifu-shi 502)

Accepted: 12 January 1983 